\title{
Proceedings of
}

\section{the United States}

\section{Nation a l M u se u m}

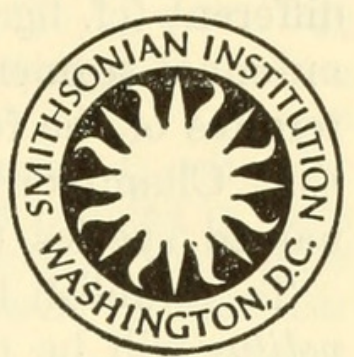

SMITHSONIAN INSTITUTION • WASHINGTON, D.C.

\section{North and Central American \\ Species of Aneurus Curtis \\ (Hemiptera: Aradidae)}

\section{By Nicholas A. Kormilev ${ }^{1}$}

Fifteen species of the genus Aneurus Curtis, 1825, have been recorded for North and Central America. In the present paper five additional species are described and a key to the 20 species is presented.

This study is based on specimens from the U.S. National Museum, Washington, D.C., and the American Museum of Natural History, New York, N.Y., loaned by Drs. Richard C. Froeschner and Peter Wygodzinsky, respectively; and information from types in the British Museum (Natural History) furnished by Dr. William J. Knight. To all these men I offer my sincere thanks.

Measurements in this paper were taken with a micromillimeter eyepiece; 25 units equal $1 \mathrm{~mm}$. For convenience, the length of the abdomen was taken from the tip of scutellum to the tip of hypopygium in the male and to segment IX in the female.

There has been some confusion concerning the identity of the Florida species, Aneurus politus Say (1832, p. 31). The original description made no reference to the important shape of the hypopygium. On the basis of five specimens from Guatemala, Champion $(1898$, p. 115) gave a short redescription with two drawings (table 7; figs. 29, 29a) and remarked about a "small and transverse" hypopygium. Comparison of three Florida specimens with three Central 
American (Mexico and Guatemala) specimens found them to be superficially similar but specifically distinct. In addition to smaller differences, the shapes of the scutellum and hypopygium are quite different (cf. figs. 14 with 17 , and 15 with 18); the proportions of the antennal segments do not coincide; and the production of the paratergites of the females differ (cf. figs. 16 and 19). Thus, it is evident that Champion's specimens probably were not politus but an unnamed species that will be described below as championi.

To establish this usage and avoid further confusion, a neotype for politus will be proposed and described under the specific treatment of that taxon.

\section{Key to North and Central American Species of Aneurus}

Clavus fully developed, reaching tip of scutellum; latter triangular with pointed apex

Subgenus Aneurosoma Champion, 1898

(contains a single species, dissimilis (Bergroth), 1889)

Clavus greatly reduced to small triangle near basolateral angle of scutellum; apex of scutellum arcuate . . . . . . . . Subgenus Aneurus Curtis, 1832

\section{Subgenus Aneurus}

1. Spiracles II to VII lateral, visible from above, VIII terminal.

vauriei Kormilev, 1964, Jamaica, Guadeloupe

At least spiracles III ventral or sublateral, not visible from above . . . 2

2. Spiracle III sublateral, placed close to border, though not visible from above. nasutus Kormilev, 1966, Guadeloupe

Spiracle III ventral, placed far from border

3. Spiracles IV ventral, placed near border, not visible from above.

1. pusillus, new species, Guatemala, Panama

Spiracles IV ventral, placed far from or close to border; when near border, spiracle V sublateral but not visible from above . . . . . . . . . . 4

4. Spiracle V lateral, visible from above . . . . . . . . . . . . . . . . 5

Spiracle V ventral or sublateral, not visible from above . . . . . . . . 7

5. Scutellum longer, ratio between length and width at least 2:3 . . . . . 6

Scutellum very short, ratio between length and width $1: 2$.

simplex Uhler, 1871, northeastern U.S.

6. Smaller species, length less than $4.0 \mathrm{~mm}$; anterior process of the head not reaching tip of antennal segment I; antennal segment II obovate.

2. aibonitensis, new species, Puerto Rico

Larger species, length about $5.0 \mathrm{~mm}$; anterior process of head produced beyond tip of antennal segment I; antennal segment II clavate.

septentrionalis Walker, 1873, eastern Canada

7. Spiracle V sublateral, not visible from above.

Spiracle V ventral, placed far from border. . . . . . . . . . . 8

3. pisoniae, new species, Puerto Rico

8. Spiracle VI lateral, visible from above . . . . . . . . . . . . . . . . 9

Spiracle VI ventral, not visible from above . . . . . . . . . . . . 14

9. Head longer than width across eyes (35:33); anterior process of the head slightly produced beyond tip of antennal segment I.

barberi Kormilev 1960, St. Lucia (Lesser Antilles)

Head as long or shorter than width across eyes; anterior process at most reaching as far as tip of antennal segment I . . . . . . . . . . 10 
10. Head shorter than width across eyes (11:12).

pygmeus Kormilev, 1966, southern U.S.

Head as long as width across eyes . . . . . . . . . . . . . . . . 11

11. Antennal segment II clavate, as long as I; larger species, length over 4.0 $\mathrm{mm}$. . . . . . . . . . . . . . 12

Antennal segment II obovate, shorter than I; smaller species, length less than $4.0 \mathrm{~mm}$. . . . . . . . . . . . . . . . . . . . . . . . 13

12. Anterior process of the head reaching tip of antennal segment I; postocular tubercle (composed of 3 minute teeth) very short, not reaching to outer border of eyes . . . . . . . . . haitiensis Kormilev 1968, Haiti

Anterior process not reaching to tip of antennal segment I; postocular tubercles strong, acute, reaching outer border of eyes.

6. championi, new species, Guatemala, Mexico

13. Scutellum wider, ratio between length and width 11.5:19; lateral borders of abdomen finely serrate . . . . . 4. froeschneri, new species, Panama

Scutellum narrower, ratio between length and width 12:16; lateral borders of abdomen roughly serrate.

minutus Bergroth, 1886, southern U. S., Central America

14. Antennal segment II obovate, III and IV cylindrical . . . . . . . . 15

Antennal segment II clavate, III tapering toward base,. IV fusiform . 17

15. Scutellum subtriangular, rounded apically; ratio between length and width 10.5:19; hypopygium small, transverse (3.5:4).

tenuis Champion, 1898, Panama, Cuba?

Scutellum semicircular; ratio of length to width $2: 3$ or $3: 4$. . . . . . . 16

16. Larger species, length over $5.0 \mathrm{~mm}$; hypopygium long and wide (10.5:10).

montanus Champion, 1898, Guatemala

Smaller species, length less than $4.5 \mathrm{~mm}$; hypopygium smaller (8:7).

fiskei Heidemann, 1904, U.S., Cuba?

17. Scutellum short, ratio of length to width $10: 16$. . . . . . . . . . . 18

Scutellum longer, ratio of length to width $15: 19$ or $20: 24$.

7. inconstans Uhler, 1871, U.S.

18. Smaller species, length less than $4.0 \mathrm{~mm}$; antennae shorter, less than twice as long as head is wide (24:12.5).

5. politus Say, 1832, southern U.S. (Florida)

Larger species, length over $5.0 \mathrm{~mm}$; antennae longer, more than twice as long as head is wide (38:16).

leptocerus Hussey, 1957, Guatemala, Panama

\section{Aneurus pusillus, new species}

\section{Figures 4-6}

MaLE.-Elongate, sides subparallel; minutely granulate. Head slightly shorter than width across eyes (o $\sigma^{\top} 10: 11.5$, ㅇ $10.5: 12$ ). Anterior process conical, not reaching to tip of antennal segment I; jugae slightly visible from above. Antenniferous tubercles small, acute, convex exteriorly. Eyes large, semiglobose, protruding. Postocular tubercles conical with blunt tip, produced as far as, or a little less than, outer borders of eyes. Vertex very finely, transversely striate. Vertex mesad of eyes with two $(1+1)$ large, ovate callosities. Antennae thin, one and one-half times as long as length of the head 
(o $14: 10$, $15: 10.5$ ); segment I barrel shaped; II obovate, much smaller and narrower; III and IV cylindrical. Relative lengths of antennal segments I to IV: $\sigma^{7} 3: 3: 2.5: 5.5$, ㅇ $3.5: 2.75: 2.75: 6$. Labium very short, reaching middle of head.

Pronotum less than half as long as maximum width $\left(\sigma^{7} 9: 19.5\right.$, o 8.5:20). Collar tiny, sinuate in front. Anterolateral angles evenly rounded, produced neither forward, nor sideways. Lateral borders of forelobe parallel; humeri parallel, strongly converging anteriorly. Hind border sinuate in the middle. Foredisc with two $(1+1)$ beanshaped callosities, and a few small callosities laterad. Hind disc extremely finely punctured, with an arcuate, slightly raised, transverse, longitudinally striate strip.

Scutellum almost as long as basal width (or 10:11, of 10:11), evenly arcuate apically; disc finely, concentrically striate.

Hemelytra reaching to the middle of tergum VII in both sexes; corium extended along basal third of scutellum.

Abdomen elongate ovate, longer than maximum width across segment IV ( $\sigma^{\top} 40.5: 25$, ㅇ 40.5:25). Connexivum narrow; PE-angles not protruding; PE-VII rounded in the male, angularly rounded in the female. Paratergites $\left(o^{x}\right)$ moderately large, subtruncate apically, reaching apical fourth of hypopygium; latter moderately large, as long as maximum width $(5: 5)$. Paratergites () triangular, very short, produced almost as far as segment IX; latter truncate posteriorly. Spiracles II lateral, III ventral, IV ventral placed nearer to border, $\mathrm{V}$ to VII lateral, VIII terminal.

CoLon.-Yellow brown or pale testaceous, partially testaceous.

Measurements.-Total length: $\sigma^{7} 2.85$, $92.85 \mathrm{~mm}$; width of pronotum: $\sigma^{7} 0.78$, ᄋ $0.80 \mathrm{~mm}$; width of abdomen: $\sigma^{7} 1.00$, ㅇ $1.00 \mathrm{~mm}$.

Holotype.- $\sigma^{7}$, Guatemala, Cacao, Trece Aguas, Alta v. Paz; Schwarz and Barber coll. (USNM type 69794).

Allotype. $\rightarrow$, collected with holotype; in the same collection.

Paratypes. - $2 \sigma^{x} \sigma^{x}$ and 4 o o , Panama, C.Z., Bohio; Schwarz coll., 6-9.II.; 1 \%, Porto Bello; Schwarz coll., 26.II; in the same and Kormilev collections.

Remarks.-Aneurus pusillus is the smallest known American species of Aneurus. It belongs to the group with evenly rounded scutellum and relatively large hypopygium. Its relation to other species is seen from the key.

\section{Aneurus aibonitensis, new species}

Figures 7,8

Female.-Elongate ovate; head, pronotum, and lateral borders of abdomen, densely and relatively roughly punctured; lateral borders of pronotum finely serrate. 
Head shorter than width across eyes (11.5:13). Anterior process conical; jugae slightly shorter than clypeus, their tips still visible from above; tip rounded, reaching to apical fourth of antennal segment I. Antenniferous tubercles short, acute, divergent. Eyes large, semiglobose, protruding. Postocular tubercles strong, dentiform, acute, with minuscule serrations on the foreborder. Vertex transversely rugose, with two $(1+1)$ large, ovate callosities mesad of eyes. Antennae moderately robust, twice as long as head (21.5:11.5); antennal segment I obovate, thick; II obovate, but half as thick as I; III and IV subcylindrical, very slightly tapering toward the base. Relative lengths of antennal segments I to IV: 4:4:4.5:9. Labium short, reaching line connecting hind borders of eyes.

Pronotum less than half as long as maximum width (12.5:27.5). Collar very thin, feebly sinuate in front. Anterior borders truncate; anterolateral angles angularly rounded, produced neither forward, nor sideways; lateral borders of forelobe straight, convergent; lateral borders of hind lobe slightly convex; both finely, but distinctly serrate. Hind border sinuate in the middle, convex laterally. Foredisc with four $(2+2)$ low callosities; hind disc densely punctured and transversely striate along posterior border laterally.

Scutellum semicircular, shorter than basal width (12.5:18); disc concentrically rugose.

Hemelytra reaching slightly over foreborder of tergum VII; corium very short, reaching basal one-fourth of scutellum; membrane densely and deeply punctured.

Abdomen elongate ovate, longer than maximum width across segment IV. Connexivum moderately wide; connexiva III to V twice as long as wide; exterior borders slightly raised, densely granulate; mesad of granulation obliquely rugose around callosities. Tergum VIII roughly, obliquely rugose. Paratergites very short, serrate, reaching middle of segment IX; latter subtruncate, slightly sinuate in the middle of posterior border. Spiracles II and V to VII lateral and visible from above, III and IV ventral and placed far from border, VIII terminal.

CoLor.-Reddish brown; membrane darker, with pale, opaque, basolateral border.

Measurements.- Total length $3.70 \mathrm{~mm}$, width of pronotum $1.10 \mathrm{~mm}$, width of abdomen $1.40 \mathrm{~mm}$.

Holotype.- - , Puerto Rico, Aibonito BF, Medina coll., VI.1961 (USNM type 69795).

Remarks.-Aneurus aibonitensis, new species, is related to A. fiskei Heidemann, 1904, but is smaller, narrower, and with different position of spiracles. 


\section{Aneurus pisoniae, new species}

Figures 9-11

\section{MaLE.-Elongate ovate.}

Head shorter than width across eyes (o 12.5:14, of 13:15). Anterior process conical with rounded tip; reaching apical fifth of antennal segment I; jugae not visible from above. Antenniferous tubercles short, subtruncate anteriorly, blunt. Eyes moderately large, protruding. Postocular tubercles blunt, with minute granulation, short, not approaching outer borders of eyes. Vertex roughly, transversely rugose, with two $(1+1)$ large, ovate callosities placed mesad of eyes. Antennae moderately thin; antennal segment I obovate, robust; II also obovate, but much narrower; III and IV subcylindrical, slightly tapering toward base. Relative lengths of antennal segments I to IV: or $4.5: 4: 5: 10$, ㅇ $5: 4.5: 5.25: 10.5$. Labium reaching line connecting the middles of eyes.

Pronotum less than half as long as maximum width (or 12.5:29, o 14:31). Collar thin, sinuate in front. Anterior borders straight, slightly oblique; anterolateral angles rounded and slightly produced forward beyond collar; lateral borders of forelobe straight, converging; lateral borders of hindlobe subparallel, convergent, rounded anteriorly. Hindborder sinuate in the middle, convex laterally. Foredisc with two $(1+1)$ bean-shaped callosities and a few callous rugae laterad of them. Hind disc finely, transversely striate anteriorly; very finely, longitudinally striate posteriorly.

Scutellum subtriangular; lateral borders moderately convex, apex angularly rounded. Scutellum shorter than basal width (o 12.5:19, o $12.5: 20)$. Disc concentrically rugose along the borders; longitudinally rugose in the middle.

Hemelytra reaching to the middle of tergum VII in both sexes; corium reaching basal fourth of scutellum.

Abdomen ovate in both sexes, longer than wide (o $53: 38.5$, ㅇ $58: 42.5$ ). Connexivum moderately wide; segments IV to VI twice as long as wide. Exterior borders of connexiva slightly raised, granulate; disc around callosities sparsely rugose. Paratergites $\left(\sigma^{7}\right)$ short, rounded, reaching apical fourth of hypopygium; latter small, shorter than its maximum width (5:6). Paratergites (o) short, forming an obtuse angle, their interior border twice as long as exterior, produced as far as segment IX; latter truncate posteriorly. Spiracles II and VI to VII lateral and visible from above, III to IV ventral, V placed close to border but not visible from above, VIII terminal.

Color.-Head, pronotum, and scutellum yellow brown; connexivum brown; membrane black; ventral side ochraceous medially, yellow brown laterally. 
Measurements.-Total length: $\sigma^{7} 3.70$, o $4.00 \mathrm{~mm}$; width of pronotum: $\sigma^{\top} 1.16$, o $1.24 \mathrm{~mm}$; width of abdomen: $\sigma^{\top} 1.54$, \& 1.70 $\mathrm{mm}$.

Holotype.- $\sigma^{7}$, Puerto Rico, Maricao; De Leon coll., 16.IV.1940, on Pisonia subcordata (USNM type 69796).

Allotype.- - , collected with holotype; in the same collection.

Paratypes. - $4 \sigma^{T} \sigma^{T}$ and 2 우, collected with holotype; in the same and Kormilev collections.

Remarks.-Aneurus pisoniae, new species, is related to A. haitiensis Kormilev (1968, p. 2), but is smaller, with lateral borders of forelobe of pronotum straight, hypopygium more narrowly rounded, paratergites shorter, and color more contrasting: yellow brown with black membrane.

\section{Aneurus froeschneri, new species}

Figures 12, 13

Female.-Elongate ovate, finely granulate.

Head slightly shorter than width across the eyes (12.5:13). Anterior process conical, rounded apically, reaching to tip of antennal segment I; jugae reaching almost to tip of clypeus, clearly visible from above. Antenniferous tubercles small, acute, convex exteriorly, and slightly divergent. Eyes moderately large, protruding. Postocular tubercles strong, dentiform, acute, reaching as far as outer margins of eyes. Vertex finely, transversely rugose, with two $(1+1)$ large, ovate callosities mesad of eyes. Antennae slender, less than twice as long as head (20.25:12.5); antennal segment I stout, obovate; II narrowly obovate; III and IV cylindrical; relative lengths of antennal segments I to IV: 4:3.75:3.75:8.75. Labium reaching line connecting middles of eyes.

Pronotum less than half as long as maximum width (11.5:27). Collar thin, sinuate in front. Anterolateral angles rounded, produced forward beyond collar; lateral borders of forelobe together with lateral notch slightly sinuate; lateral borders of hind lobe slightly convex, converging anteriorly; both finely serrate, particularly in the lateral notch. Hind border sinuate medially, angularly produced laterally. Foredisc with two $(1+1)$ large ovate callosities, and granulate laterad of them. Hind disc very finely granulate anteriorly and medially; very finely, transversely striate along posterior border laterally.

Scutellum shorter than basal width (11.5:19); lateral borders weakly convex, apex evenly rounded.

Hemelytra reaching almost to hind border to tergum VII. Corium reaching basal third of scutellum; membrane densely and roughly punctured. 
Abdomen elongate ovate, longer than maximum width across segment IV (53:38). Connexivum moderately wide. Paratergites small, rounded, reaching as far as segment IX; latter truncate posteriorly. Spiracles II and VI to VII lateral and visible from above, III to $\mathrm{V}$ ventral and placed far from border, VIII terminal.

CoLor.-Dark yellow brown; connexivum brown; membrane dark brown.

Measurements.-Total length $3.64 \mathrm{~mm}$, width of pronotum 1.08 $\mathrm{mm}$, width of abdomen $1.52 \mathrm{~mm}$.

Holotype.-o, Panama, El Valle; N.L.H. Krauss coll., XI.1946 (USNM type 69797).

Remarks.- It is a pleasure to name this species for Dr. Richard C. Froeschner, by whose kind offices I have had an opportunity to study this lot as well as many other Aradidae from the collections in his charge.

Aneurus froeschneri, new species, is related to A. minutus Bergroth, 1886, from which it differs as indicated in the key.

\section{Aneurus politus Say}

Figures $14-16$

Aneurus politus Say, 1832, p. 31.

MALE.-Elongate ovate; shiny.

Head as long as width across eyes ( $\sigma^{7} 12.5: 12.5$, 15:15). Anterior process conical, rounded anteriorly, reaching slightly beyond the tip of antennal segment I; jugae adherent to clypeus, not visible from above. Antenniferous tubercles short, truncate anteriorly, not acute. Eyes moderately large, protruding. Postocular tubercles stout, dentiform, blunt, produced as far as lateral margins of eyes. Vertex transversely rugose, with two $(1+1)$ moderately large, ovate callosities mesad of eyes. Antennae almost twice as long as head (o 24:12.5, ㅇ 29.5:15); antennal segment I barrel shaped; II and III clavate; IV elongate fusiform; relative lengths of antennal segments I to IV: $0^{7} 3.5: 5: 5.5: 10$, ㅇ 4:6.5:7.5:11.5. Labium reaching line connecting hind borders of eyes.

Pronotum less than half as long as maximum width (or 10:25, ㅇ 12.5:30). Anterior borders straight, slightly oblique; anterolateral angles rounded, slightly produced beyond collar; lateral borders of forelobe together with lateral notch moderately sinuate; lateral borders of hind lobe sligh tly convex, strongly converging anteriorly; hind border sinuate, medially. Foredisc with four $(2+2)$ large, ovate, blurred callosities. Hind disc very finely, transversely striate anteriorly and along hind border laterally; shiny in the middle.

Scutellum transverse, much shorter than basal width (o $10: 16.5$, 11:20); tip widely arcuate. Disc with an elongate callous spot 
in the middle anteriorly; concentrically striate around callosity.

Hemely tra reaching to the middle of tergum VII; corium reaching basal third of scutellum; membrane finely punctured, finely wrinkled around punctures; exterior border of membrane smooth, transparent.

Abdomen longer than maximum width across segment IV ( $\sigma^{x}$ $55: 37.5$, ㅇ $60: 56)$. Connexivum moderately wide. Paratergites $\left(\sigma^{7}\right)$ long, subtriangular, rounded apically, reaching apical fourth of hypopygium; latter large, elongate, rounded at base and apically (10:8). Paratergites (o) large, rounded apically, produced far beyond small and short segment IX, latter slightly sinuate posteriorly. Spiracles II and VII lateral, visible from above; III to VI ventral, placed far from border; VIII terminal.

CoLor.-Reddish brown; forelobe of pronotum, tergum, prosternum, meso- and metasternum around coxae, pale yellow brown; membrane brown.

Measurements.--Total length: $\sigma^{7} 3.60$, $+4.20 \mathrm{~mm}$; width of pronotum: $\sigma^{\top} 1.00$, o $1.20 \mathrm{~mm}$; width of abdomen: $\sigma^{\top} 1.50$, o $2.24 \mathrm{~mm}$.

Neотype.- $\sigma^{7}$, U.S.A., Florida, Biscayne; 21.V.1887, ex Uhler collection (USNM type 69798).

Examined specimens.-1 9 , Florida, Biscayne; 26.V.1887, ex Uhler collection (USNM). 1 \&, Florida, Belle Air; ex collections of Mrs. A. T. Slosson (AMNH).

\section{Aneurus championi, new species}

Figures 17-19

Female.-Elongate ovate, shiny.

Head almost as long as width across eyes (ㅇ 15.5:16, or 15:14.5). Anterior process conical, reaching three-fourths of antennal segment I; tips of jugae slightly visible from above. Antenniferous tubercles acute exteriorly, slightly divergent. Eyes semiglobose, protruding. Postocular tubercles dentiform, acute, slightly produced beyond outer border of eyes (o), or reaching to latter $\left(\sigma^{7}\right)$. Infraocular, ovate, callous spots large. Vertex transversely rugose. Antennae slender, less than twice as long as head (ㅇ 27.5:15.5, ơ 24.5:15); antennal segment I obovate; II clavate; III subcylindrical, tapering toward base; IV cylindrical; relative lengths of antennal segments I to IV: o 5.5:5.5:5.5:11, o $\sigma^{7} 5: 5: 5: 10.5$. Labium reaching line connecting hind borders of eyes.

Pronotum less than half as long as its maximum width (ㅇ 15:34, $\sigma^{7}$ 12.5:30). Collar sinuate. Anterolateral angles rounded, very slightly produced forward beyond collar. Lateral borders parallel at humeri, strongly convergent and sinuate anteriorly. Hind border sinuate in the middle. Foredisc with two $(1+1)$ bean-shaped calloused spots and with a few semifused callosities laterad of them; granulate 
in front of callosities. Hind disc finely longitudinally striate, with exception of two $(1+1)$ transverse, glabrous spots.

Scutellum subtriangular with subtruncate or widely arcuate apex. Disc concentrically rugose around mediobasal longitudinal rugae.

Hemelytra reaching middle of tergum VII (o), or hind border of tergum VI $\left(\sigma^{7}\right)$.

Abdomen longer than its maximum width across segment IV (ㅇ 69:50, or 60:46). Connexivum relatively wide; PE-angles barely protruding. Tergum VIII (o) small, narrower than head (12:16). Segment IX more than one-third width of head (6:16); paratergites rounded, reaching segment IX. In male, paratergites small, divergent, produced beyond small, transverse hypopygium; the latter much shorter than wide (3:5). Spiracles: II, VI, and VII lateral and visible from above; III and IV ventral and placed far from border; VIII terminal.

CoLor.-Yellow brown, venter paler; membrane infuscate; labium and tarsi yellow.

Measurements.-Total length: o 4.68, ơ $3.90 \mathrm{~mm}$; width of pronotum: 우 1.36, ơ $1.20 \mathrm{~mm}$; width of abdomen: 우 2.00, o $1.84 \mathrm{~mm}$.

Ноцотүре.-o, Guatemala, Chicacao; E. J. Hambleton coll., 7.VII.1945 (USNM type 69799).

Allotype.- - ${ }^{\nearrow}$, Mexico, Vera Cruz, Peñuela; H. Dybas coll., 17.VII.1941; deposited in the Field Museum of Natural History, Chicago.

Paratrpes. -2 우 and $1 \sigma^{x}$, collected with allotype; in the Field Museum of Natural History, Chicago, and Kormilev collection.

REMarks.-This species is named for the eminent British entomologist, G. C. Champion, who did the first comprehensive survey of Central American Aradidae.

\section{Aneurus inconstans Uhler}

Figures 1-3

Aneurus inconstans Uhler, 1871, p. 105.

In the collections examined, this species was sometimes confused with $A$. septentrionalis Walker. The key given earlier plus the three drawings will permit ready separation of the two forms. 
BERGRoth, E.

\section{Literature Cited}

1866. Ueber einige amerikanische Aradiden. Wiener Ent. Zeit., vol. 5, pp. 97-98.

Champion, G. C.

1898. Aradidae. Pp. 65-117 (with 3 pls.) in vol. 2 of Heteroptera in Godman and Salvin, Biologia Centrali-Americana.

Curtis, J.

1825. British entomology, vol. 2, pl. 86. London.

Heidemann, O.

1904. Notes on North American Aradidae, with descriptions of two new species. Proc. Ent. Soc. Washington, vol. 6, pp. 161-165.

Hussey, R. F.

1957. Two changes of name in Hemiptera (Aneuridae and Miridae). Florida Ent., vol. 40, p. 80.

Kormilev, N. A.

1960. Notes on Neotropical Aradidae, XI (Hemiptera). Journ. New York Ent. Soc., vol. 68, pp. 208-220.

1966. Notes on Aradidae in the U.S. National Museum, IV. Proc. U.S. Nat. Mus., vol. 119, no. 3548, pp. 1-25.

1968. Notes on Aradidae in the U.S. National Museum, V. Proc. U.S. Nat. Mus., vol. 125, no. 3651, pp. 1-16, 1 fig.

SAY, T.

1832. Descriptions of new species of heteropterous Hemiptera in North America, 39 pp. New Harmony, Indiana. [Reprinted in Le Conte, ed., Complete writings of T. Say . . . , 1859, vol. 1, pp. 310368.]

UHLER, P. R.

1871. Notices on some Heteroptera in the collection of Dr. T. W. Harris. Proc. Boston Soc. Nat. Hist., vol. 14, pp. 93-109.

WALKER, F.

1873. Catalogue of the specimens of Hemiptera Heteroptera in the collection of the British Museum, pt. VII, pp. 1-213. 

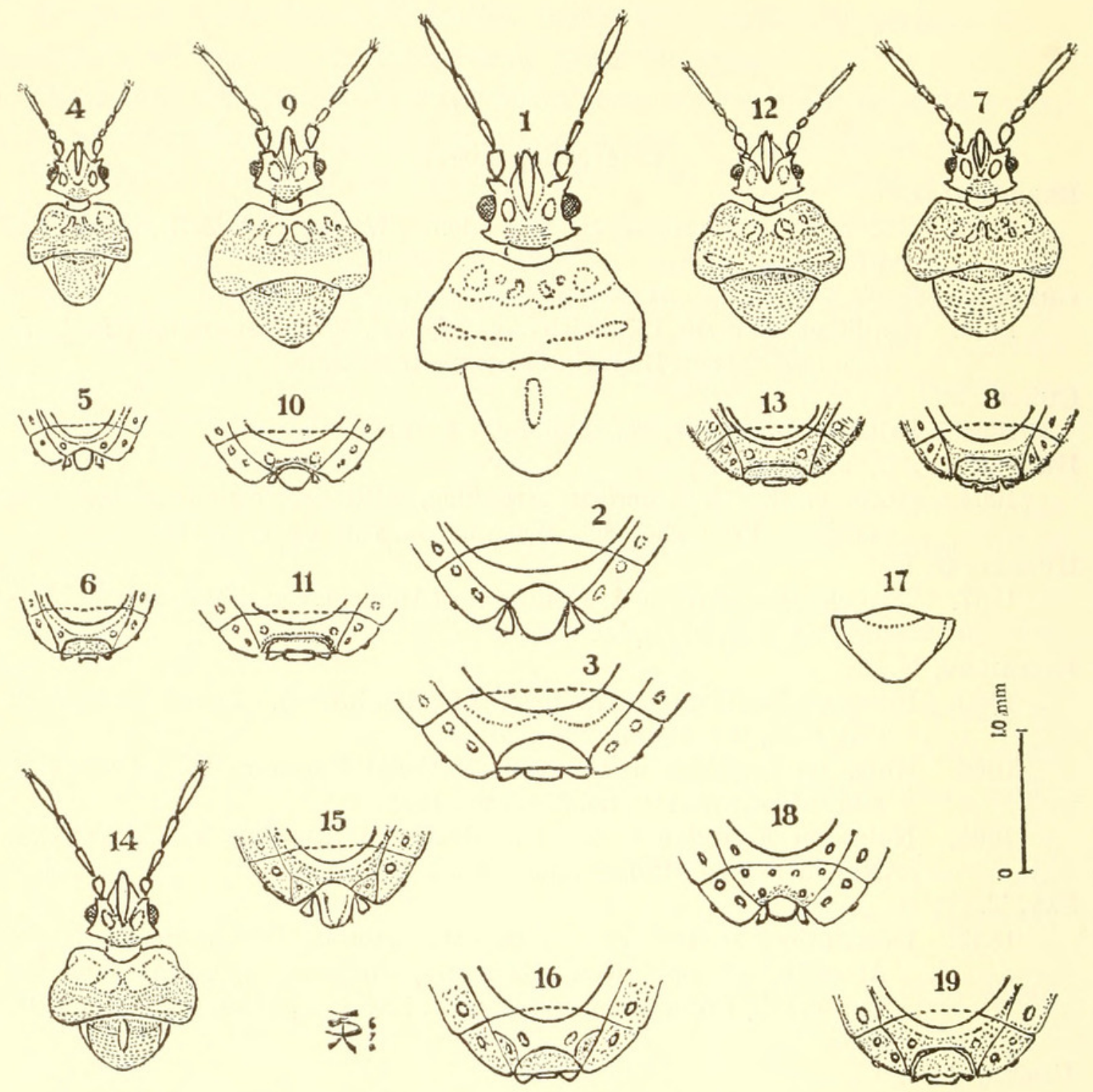

Figures 1-19.-Aneurus inconstans Uhler 1871: 1, head, pronotum, and scutellum, ơ'; 2, apex of abdomen from above, $\sigma^{\top} ; 3$, same, + . Aneurus pusillus, new species: 4 , head pronotum, and scutellum, $\sigma^{7} ; 5$, apex of abdomen from above, $\sigma^{7} ; 6$, same, + . Aneurus aibonitensis, new species: 7 , head, pronotum, and scutellum, $q ; 8$, apex of abdomen from above, + . Aneurus pisoniae, new species: 9, head, pronotum, and scutellum, $\sigma^{\top} ; 10$, apex of abdomen from above, $\sigma^{\top} ; 11$, same, $q$. Aneurus froeschneri, new species: 12, head, pronotum, and scutellum, $\% ; 13$, apex of abdomen from above, + . Aneurus politus Say 1832: 14, head, pronotum, and scutellum, $\sigma^{7} ; 15$, apex of abdomen from above, $\sigma^{x} ; 16$, same, + . Aneurus championi, new species: 17 , scutellum, $\sigma^{x} ; 18$, apex of abdomen from above, $\sigma^{x} ; 19$, same, $q$. 


\section{$2 \mathrm{BHL}$ Biodiversity Heritage Library}

1968. "North and Central American species of Aneurus Curtis (Hemiptera: Aradidae)." Proceedings of the United States National Museum 125(3657), 1-12. https://doi.org/10.5479/si.00963801.125-3657.1.

View This Item Online: https://www.biodiversitylibrary.org/item/52774

DOI: https://doi.org/10.5479/si.00963801.125-3657.1

Permalink: $\underline{\text { https://www.biodiversitylibrary.org/partpdf/51046 }}$

\section{Holding Institution}

Smithsonian Libraries

\section{Sponsored by}

Smithsonian

\section{Copyright \& Reuse}

Copyright Status: Public domain. The BHL considers that this work is no longer under copyright protection.

This document was created from content at the Biodiversity Heritage Library, the world's largest open access digital library for biodiversity literature and archives. Visit BHL at https://www.biodiversitylibrary.org. 